\title{
Acceptability of peanut candy with different proportions of Kinako soy flour and substitution of sucrose by sucralose
}

\author{
Aceitabilidade de paçoca de amendoim \\ com diferentes proporções de Farinha \\ de soja Kinako e substituição \\ da sacarose por sucralose
}

\author{
Mayra Fernanda Sousa CAMPOS ${ }^{1}$ (D) 0000-0002-1823-8151 \\ Cecília Teresa Muniz PEREIRA ${ }^{1}$ ID 0000-0001-9023-0683 \\ Alessandra Cazelatto de MEDEIROS ${ }^{1}$ iD 0000-0002-3539-1713 \\ Helena Maria André BOLINI ${ }^{1}$ ID 0000-0001-9841-4479
}

A B S T R A C T

\section{Objective}

The aim of this research was to produce new formulations of peanut "paçoca" candy, replacing peanut flour with Kinako flour, and check if the addition of this ingredient bears a negative impact on acceptance.

\section{Methods}

Eight formulations of peanut "paçoca" candy, sweetened with sucrose and sucralose, were prepared with partial and total replacement of peanut flour by Kinako flour. The assessment of the acceptance was carried out by 121 tasters, using the $9 \mathrm{~cm}$ unstructured hedonic scale. Willingness to purchase the different samples was evaluated by a 5-point scale. In addition, a sociodemographic questionnaire was applied. The results were submitted to ANOVA and Tukey's test.

\footnotetext{
1 Universidade Estadual de Campinas, Departamento de Alimentos e Nutrição, Faculdade de Engenharia de Alimentos. R. Monteiro Lobato, n. 80, Cidade Universitária Zeferino Vaz, 13083-862, Campinas, SP, Brasil. Correspondence to: M.F.S. CAMPOS. E-mail: <mayra.campos@blv.ifmt.edu.br>.
}

How to cite this article

Campos MFS, Pereira CTP, Medeiros AC, Bolini HMA. Acceptability of peanut candy with different proportions of Kinako soy flour and substitution of sucrose by sucralose. Rev Nutr. 2021;34:e200293. https://doi.org/10.1590/1678-9865202134200293 


\section{Results}

Most of the survey participants stated that they rarely consume soybeans and/or soy derivatives. Regarding acceptance, among the eight formulations analyzed, samples sweetened with sucrose, containing either $100 \%$ peanut flour and $50 \%$ peanut flour replaced by Kinako flour, did not differ significantly between them $(p<0.05)$ and were the most appreciated by consumers considering the flavor and overall impression attributes.

\section{Conclusion}

The results showed that replacing peanut flour with Kinako flour in peanut "paçoca" candy is feasible and that more sensory studies are needed to add this flour to other foods, to provide the nutritional benefits present in soybean.

Keywords: Soy. Peanut. Acceptance.

\section{RE S U M O}

\section{Objetivo}

O objetivo deste estudo foi produzir novas formulações de paçoca de amendoim, substituindo o amendoim pela farinha Kinako e verificar se a inserção deste ingrediente afeta negativamente na aceitação.

\section{Métodos}

Foram elaboradas oito formulações de doce de amendoim "tipo paçoca", adoçados com sacarose e sucralose, com substituição parcial e total da farinha de amendoim por farinha Kinako. A avaliação de aceitação foi realizada por 121 provadores, através da utilização de escala hedônica não estruturada de $9 \mathrm{~cm}$. A intenção de compra das amostras foi avaliada por uma escala de 5 pontos. Além disso, foi utilizado um questionário sociodemográfico. Os resultados foram submetidos à ANOVA, seguido pelo teste de médias de Tukey.

\section{Resultados}

A maioria dos participantes afirmou consumir soja elou derivados raramente. Em relação à aceitabilidade, dentre as oito formulações analisadas, as amostras adoçadas com sacarose, contendo 100\% de amendoim e com 50\% de substituição de amendoim por farinha Kinako, não diferiram significativamente entre si $(p<0,05)$ e foram as mais apreciadas pelos consumidores no atributo sabor e impressão Global.

\section{Conclusão}

Os resultados demonstraram que é viável a substituição de amendoim por farinha Kinako e que são necessários mais estudos sensoriais visando a inserção desta farinha em outros alimentos, com intuito de agregar os benefícios nutricionais presentes na soja.

Palavras-chave: Soja. Amendoim. Aceitação.

\section{INTRODUCTION}

The elaboration of protein products is necessary in many developing countries. Peanuts and soybeans that contain large amounts of protein are low-cost sources of protein and contribute to this purpose [1].

Comparing the protein content of both ingredients, peanuts have an average of $27.2 \%$ protein and soybean seeds $40.4 \%$ [2]. In addition, the amino acid composition of soybean approximates the amino acid composition of animal foods; hence it is often used as a replacement for meat protein [3].

Kinako is a soy flour, traditional in Japanese cuisine, made from the direct roasting of dry whole grains and their subsequent grinding [4]. Consuming three soy or Kinako tablespoons a day meets the minimum adult daily isoflavone requirements. In addition, Kinako flour is rich in protein and soluble fibers that are effective in controlling type II diabetes and lowering total cholesterol blood levels and Low Density Lipoprotein (LDL) cholesterol [4], [5].

Brazil produces a very popular peanut candy, known as paçoca [6]. The incorporation of Kinako flour and the replacement of sugar with sucralose in a paçoca candy promote the incorporation of the 
benefits of soy in a food with indulgent characteristics, in addition to contributing to the reduction of sugar consumption by the population.

However, it is important to emphasize that, regardless of the product, and its potential benefits, successful introduction is ultimately determined by the consumer's sensory acceptance. Any composition change yields a different product. Therefore, producers ought to be aware if the change is important that is, if it is recognized by consumers and affects their purchase intention. Which product's features or combinations of features have changed? What can technology do to compensate should this change have negative effects? Answers to these kinds of questions are best obtained through the use of sensory assessment tests [7].

Considering the soy nutritional quality and its benefits, it is necessary to seek alternatives for the inclusion of this ingredient in the diet and the diversification of products without added sugar.

Given the above, this study aimed to develop paçoca-type peanut candy formulations with different proportions of Kinako Flour, sweetened with sucrose and sucralose, to determine the acceptability, purchase intention of the different samples and the frequency of consumption by the tasters in relation to soy and derivative products.

\section{METHODS}

Samples of paçoca-type peanut candy with different proportions of Kinako flour were prepared at the Laboratório de Ciência Sensorial e Estudo do Consumidor (LCSEC, Sensory Science and Consumer Study Laboratory), at the Faculdade de Engenharia de Alimentos (FEA, Faculty of Food Engineering) of Universidade Estadual de Campinas (UNICAMP).

The preparation of the samples and performance of the tests took place after approval by the Research Ethics Committee of the UNICAMP under CAAE Opinion No. 69756317.4.0000.5404

The following ingredients were purchased on the market in Campinas-SP: soybean Natubom ${ }^{\circledR}$ (Campo Grande, Brazil); roasted no-salt peanuts Santa Helena ${ }^{\circledR}$ (Ribeirão Preto, Brazil); commercial extra fine Santa Isabe $\left.\right|^{\circledR}$ sucrose (Novo Horizonte, Brazil); Cisne ${ }^{\circledR}$ refined salt (Cabo-Frio, Brazil); Copra ${ }^{\circledR}$ flavorless coconut oil (Maceió, Brazil); Maltodextrin, Fructooligosaccharide (FOS) and Sucralose Sweetmix (Sorocaba, Brazil).

The paçoca formula was determined based on the study of Lima et al. [6]. Initially, the replacements of the percentage of peanut flour by Kinako flour were defined (Table 1).

After defining the proportions of peanuts and Kinako flour, eight candy formulations were developed (Table 2): two containing 100\% peanut flour, one sweetened with sucrose (Psac) and another with sucralose (Psuc); three formulations (F1sac, F2sac, F3sac) with, , 50:50, 25:75, 0:100 (m:m), proportions of peanut and Kinako flour respectively, sweetened with sucrose; three formulations (F1suc, F2suc, F3suc) with 50:50, 25:75, 0:100 (m:m) proportions of peanut and Kinako flour, sweetened with sucralose.

Table 1 - Percentages of peanut flour and Kinako flour used in the formulations.

\begin{tabular}{|c|c|c|}
\hline \multirow{2}{*}{ Formulations } & \multicolumn{2}{|c|}{ Flour (\%) } \\
\hline & Peanut Floor & Soybean flour \\
\hline $\mathrm{P}_{\text {sad }} / \mathrm{P}_{\text {suc }}$ & 100 & - \\
\hline $\mathrm{F} 1_{\text {sacl }} \mathrm{F} 1_{\text {suc }}$ & 50 & 50 \\
\hline $\mathrm{F} 2_{\text {sacl }} \mathrm{F} 2_{\text {suc }}$ & 25 & 75 \\
\hline $\mathrm{F} 3_{\text {sacl }} \mathrm{F}_{\text {suc }}$ & - & 100 \\
\hline
\end{tabular}

Note: $\mathrm{P}_{\text {sac }} / \mathrm{P}_{\text {suc }}: 100 \%$ peanut flour; $F 1_{\text {sac }} / F 1_{\text {suc }}: 50 \%$ peanut flour and $50 \%$ soy flour; $F 2_{\text {sac }} / F 2_{\text {suc }}: 75 \%$ peanut flour and $25 \%$ soy flour; $F 3_{\text {sac }} / F 3_{\text {suc }}: 100 \%$ soy flour. 
Table 2 - Raw materials used for the formulation of paçoca-type candies with Kinako flour.

\begin{tabular}{lcccccccc}
\hline \multirow{2}{*}{ Samples } & \multicolumn{7}{c}{ Ingredients (\%) } \\
\cline { 2 - 8 } & Kinako Flour & Peanut Flour & Sucrose & Sodium & Maltodextrin & FOS & Sucralose & Coconut Oil \\
\hline $\mathrm{P}_{\text {sac }}$ & - & 62 & 37 & 1 & - & - & 0.04 & - \\
$\mathrm{F} 1_{\text {sac }}$ & 31 & 31 & 37 & 1 & - & - & 0.04 & - \\
$\mathrm{F} 2_{\text {sac }}$ & 46.05 & 15.5 & 37 & 1 & - & - & 0.04 & - \\
$\mathrm{F}_{100}$ & 59 & - & 37 & 1 & - & - & 0.04 & 3 \\
$\mathrm{P}_{\text {suc }}$ & - & 62 & - & 1 & 28.96 & 8 & 0.04 & - \\
$\mathrm{F}_{\text {suc }}$ & 31 & 31 & - & 1 & 28.96 & 8 & 0.04 & - \\
$\mathrm{F}_{\text {suc }}$ & 46.5 & 15.5 & - & 1 & 28.96 & 8 & 0.04 & - \\
$\mathrm{F}_{\text {suc }}$ & 59 & - & - & 1 & 28.96 & 8 & 0.04 & 3 \\
\hline
\end{tabular}

Note: $P_{\text {sac }}: 100 \%$ sucrose-sweetened peanut flour; $F 1_{\text {sac }}: 50 \%$ peanut flour and $50 \%$ soy flour sweetened with sucrose, $\mathrm{F2}_{\text {sac }}: 75 \%$ peanut flour and $25 \%$ soy flour sweetened with sucrose; $\mathrm{F}_{\text {sac }}$ : 100\% soy flour sweetened with sucrose; Psuc: $100 \%$ sucralose-sweetened peanut flour; $\mathrm{F}_{\text {suc }}: 50 \%$ peanut flour and $50 \%$ soy flour sweetened with sucralose, $\mathrm{F}_{\text {suc }}$ : $75 \%$ peanut flour and $25 \%$ soy flour sweetened with sucralose; $\mathrm{F}_{\text {suc: }}$ : $100 \%$ soy flour sweetened with sucralose. FOS: Fructooligosaccharide.

For the preparation of soy flour, the grain was roasted at $150^{\circ} \mathrm{C}$ for 30 minutes in a ClimaPlusCombi Combi Oven - CPC (Rational ${ }^{\circledR}$, Germany). Afterwards, soy and peanuts were separately crushed in an industrial blender, TA-02-N (Skymsen ${ }^{\circledR}$, Brazil). The flours obtained were sieved in 60 mesh sieve to obtain uniformity of the granules and then packed in appropriate containers for later use in the formulations.

The dry ingredients (Kinako flour, peanut flour, refined salt, sucrose, maltodextrin, FOS and sucralose) were weighed and then homogenized for 2 minutes in an industrial blender, TA-02-N (Skymsen ${ }^{\circledR}$, Brazil). In samples F3sac and F3suct, formulated with 100\% soy flour, $3 \%$ deodorized coconut oil was added to improve consistency, facilitating the pressing and cutting operations.

The mixtures obtained were pressed in a $140.6 \mathrm{kgf} / \mathrm{cm}^{2}$ hydraulic press (SchwingSiwa ${ }^{\circledR}$, Brazil) up to $70.3 \mathrm{kgf} / \mathrm{cm}^{2}$ pressure, for six minutes and then cut into squares $(2 \mathrm{~cm} \times 2 \mathrm{~cm})$. The candies were wrapped in PVC plastic film and stored protected from light and at room temperature until the time of sensory analysis

The tests were applied at UNICAMP's LCSEC, in individual booths under white light, with temperature controlled at $25^{\circ} \mathrm{C}$. The samples were served to the tasters in disposable white plastic mini dishes, coded with random three-digit numbers, in balanced complete blocks [8]. Inside the booths, the tasters had water available and a water cracker to cleanse the palate between samples intake.

One hundred twenty-one volunteer tasters participated in the test to assess acceptance. Initially, the judges signed the Informed Consent Form and answered a questionnaire containing questions related to age, gender and frequency of consumption of soy-based foods.

A 9 point unstructured hedonic scale was used, with limits being the terms "I Disliked Extremely" on the left and "Liked Extremely" on the right, for the attributes appearance, aroma, flavor, texture and impression [9].

The purchase intention of the tasters in relation to the samples was also evaluated, through the 5 points, purchase intention scale, which ranged from 1 - certainly would buy to 5 - certainly not. The consumer test was evaluated using Analysis of Variance (ANOVA), Tukey's test of means with the aid of the Statistical Analysis System (SAS) 9.4 program.

\section{R E S U L T S}

A total of 121 tasters participated in the acceptance test, with $68 \%$ of the tasters being female and $32 \%$ male. Most participants (87.6\%) were between 18 and 30 years old, and $8.4 \%$ were between 31 and 
40 years old. The tasters in the age range of 41 to 50 years were $3 \%$ and only $1 \%$ of the tasters were over 50 years old.

Regarding the level of education, 54\% of participants attended higher education courses and $7 \%$ had completed higher education, followed by $36 \%$ of graduate students and $3 \%$ with complete high school.

Data regarding soybean and/or soy products frequency of consumption were collected (Figure 1). The results obtained in this investigation demonstrate that the participants profile included mostly young people with a high level of education and the vast majority $(65.80 \%)$ seldom consumed soybean and/or soy by-products.

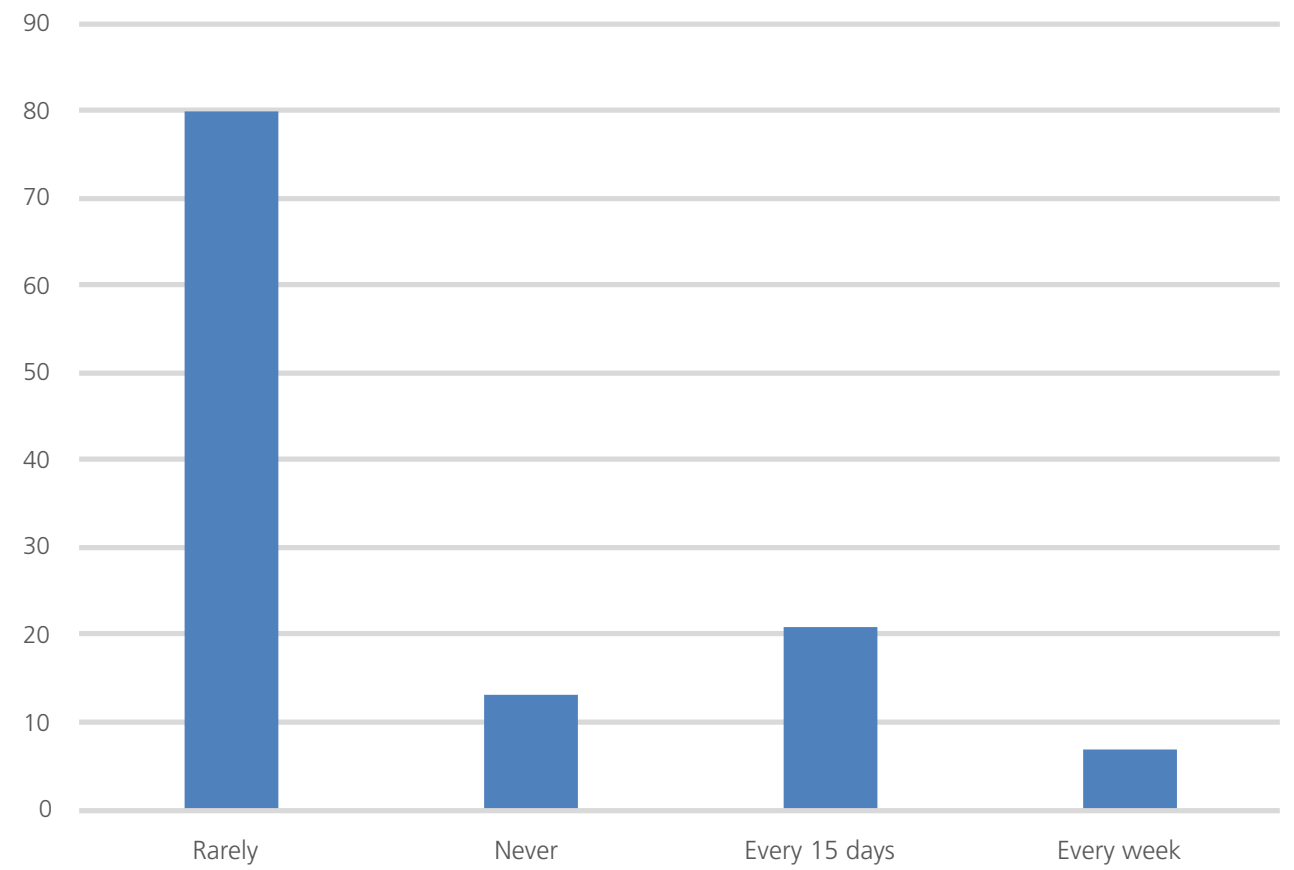

Figure 1 - Consumption frequency of soybean and/or soy products by the study participants.

According to the data collected, we observe that the consumption of soybeans and soy derivatives is low.

Regarding the averages obtained in the acceptance test, for the eight candy samples, we can observe (Table 3 ) that the samples Psac and F1sac did not differ significantly $(p \leq 0.05)$ in relation to appearance, aroma, flavor, texture and global impression and obtained the highest sensory averages in most attributes; they were the samples most preferred by the tasters. Nevertheless, for all attributes, all samples means were above the indifference score $[4,5]$.

When sucrose was replaced by sucralose, it was observed that the samples with the sweetener in their composition differed statistically $(p>0.05)$ from those that were sweetened with sucrose with regard to global impression, with the exception of the F3 formulation.

When comparing samples sweetened with sucrose versus samples sweetened with sucralose, it is noted that the diet formulations are lighter color. Possibly the inclusion of ingredients such as Maltodextrin and Fructooligosaccharide contributed to this result. Both ingredients have a white tone. 
Table 3 - Average values attributed by consumers for the eight peanut candy samples with replacement of Kinako flour.

\begin{tabular}{|c|c|c|c|c|c|c|c|c|c|}
\hline \multirow{2}{*}{ Attributes } & \multicolumn{9}{|c|}{ Samples } \\
\hline & $\mathrm{P}_{\mathrm{sac}}$ & $\mathrm{F} 1_{\text {sac }}$ & $\mathrm{F} 2_{\mathrm{sac}}$ & $\mathrm{F}_{\mathrm{sac}}$ & $P_{\text {suc }}$ & $\mathrm{F} 1_{\text {suc }}$ & $\mathrm{F} 2_{\text {suc }}$ & $\mathrm{F} 3_{\text {suc }}$ & MSD* \\
\hline Appearance & $7.22^{a}$ & $7.11^{\mathrm{ab}}$ & $6.82^{\mathrm{ab}}$ & $6.52^{\mathbf{b}}$ & $6.57^{b c}$ & $6.69^{b c}$ & $6.62^{b c}$ & $6.22^{c}$ & 0.52 \\
\hline Aroma & $6.81^{\mathrm{a}}$ & $6.46^{\mathrm{ab}}$ & $5.97^{b}$ & $5.84^{\mathbf{b}}$ & $5.90^{\mathbf{b}}$ & $5.75^{\mathbf{b}}$ & $5.90^{\mathbf{b}}$ & $5.39^{b}$ & 0.64 \\
\hline Taste & $7.52^{\mathrm{a}}$ & $7.32^{\mathrm{a}}$ & $6.10^{\mathbf{b}}$ & $5.84^{\mathbf{b}}$ & $6.24^{\mathbf{b}}$ & $5.98^{\mathbf{b}}$ & $4.90^{c}$ & $4.06^{d}$ & 0.69 \\
\hline Texture & $6.75^{\mathrm{a}}$ & $6.56^{\mathrm{a}}$ & $5.91^{b c}$ & $5.82^{b c}$ & $6.35^{\mathrm{ab}}$ & $5.73^{b c}$ & $5.36^{c}$ & $4.67^{d}$ & 0.66 \\
\hline Overall impression & $7.25^{\mathrm{a}}$ & $7.12^{\mathrm{a}}$ & $6.37^{\mathbf{b}}$ & $5.76^{\mathrm{bc}}$ & $6.38^{\mathbf{b}}$ & $5.92^{\mathbf{b c}}$ & $5.37^{c}$ & $4.95^{c}$ & 0.62 \\
\hline
\end{tabular}

Note: "MSD: Minimum Significant Difference to establish difference according to Tukey's test $(p<0.05)$; Means with equal letters on the same line do not differ statistically from each other $(p<0.05)$; $n=121$; Flour concentration (peanut/soybean) in the formulations: $P_{\text {sac }}: 100 \%$ peanut flour sweetened with sucrose; $\mathrm{F1}_{\text {sac }}$ : $50 \%$ peanut flour and $50 \%$ soy flour sweetened with sucrose, $\mathrm{F}_{\text {sac }}: 75 \%$ peanut flour and $25 \%$ soy flour sweetened with sucrose; $\mathrm{F}_{\text {sac }}: 100 \%$ soy flour sweetened with sucrose; $\mathrm{P}_{\text {suc }}: 100 \%$ sucralose-sweetened peanut flour; $\mathrm{F}_{\text {suc }}$ : $50 \%$ peanut flour and $50 \%$ soy flour sweetened with sucralose, $F 2_{\text {suc }}: 75 \%$ peanut flour and $25 \%$ soy flour sweetened with sucralose; $F 3_{\text {suc: }}: 100 \%$ soy flour sweetened with sucralose.

According to the purchase intention data (Figure 2), more than $50 \%$ of consumers would certainly buy the Psac and F1sac samples and only 3\% the F3suc sample.

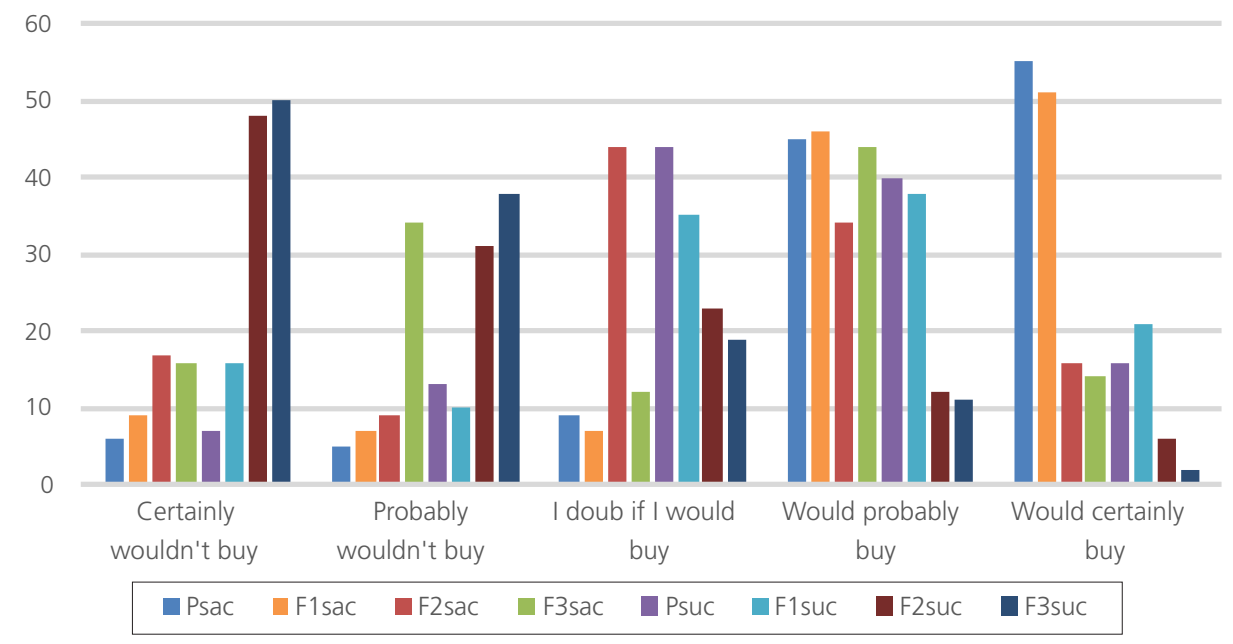

Figure 2 - Purchase intent graph for the eight peanut candy samples with different proportions of Kinako flour.

Note: Psac: 100\% sucrose-sweetened peanut flour; F1sac: 50\% peanut flour and 50\% soy flour sweetened with sucrose, F2sac: $75 \%$ peanut flour and $25 \%$ soy flour sweetened with sucrose; F3sac: $100 \%$ soy flour sweetened with sucrose; Psuc: $100 \%$ sucralose-sweetened peanut flour; F1suc: $50 \%$ peanut flour and $50 \%$ soy flour sweetened with sucralose, F2suc: $75 \%$ peanut flour and $25 \%$ soy flour sweetened with sucralose; F 3 suc: $100 \%$ soy flour sweetened with sucralose.

\section{DISCUSSION}

Consumer's acceptance of soy-based functional foods is not well known [10]. Despite the fact that Brazil is a major global producer of soybean, studies found that the consumption of soy and derivatives by Brazilians is low, corroborating the data found in this investigation $[11,12]$.

Regarding the acceptability of the products in this study, samples with total replacement of peanut flour by Kinako flour were less appreciated by consumers. The higher the percentage of peanut replacement with Kinako flour, the lower the acceptance averages attributed. Similar results were found in the study by Romanchik-Cerpovicz, Abbott \& Dent [13]. 
However, Faria et al. [14] evaluated the effect of replacing whey protein with soy protein isolate in cereal bar formulations. Sensory evaluation was performed by Diabetic (DB) and Non-Diabetic (NDB) consumers. The tasters did not identify a significant difference $(p \leq 0.05)$ between the samples; however, the acceptability test showed that the PB1 sample containing $75 \%$ of isolated soy protein obtained more frequently a score of 9 (36.30\%), followed by PB2 and PB3 (both $34.09 \%$ ).

Mariani et al. [15] evaluated the sensory characteristics of gluten-free biscuits made from rice flour, rice bran and soy flour. Only the texture attribute of the biscuit made with rice bran and soy flour was considered inferior to the standard biscuit. The other attributes (appearance, aroma, flavor and overall impression) were considered by the evaluators to be of similar quality to the standard biscuit. Biscuits made from rice and soy flour and rice bran (FAFEFS) revealed a higher purchase intention.

Regarding the replacement of sucrose by sucralose in the candies prepared in this trial, it is noted that the diet formulations are clearer. Possibly the inclusion of ingredients such as Maltodextrin and Fructooligosaccharide contributed to this result, reflecting on the data for appearance (Table 3). Both ingredients have a white tone. For Morais et al. [16] the color is directly influenced by the raw materials used in the formulation.

The formulations developed in this study, with total replacement of peanuts by soybeans, had a lower degree of acceptance compared to the others; however, for all attributes, all samples had averages above 4.5. Considering that a 9 point scale was used, scores above 4.5 are considered positive for acceptance, while scores below 4.5 were considered negative.

\section{CONCLUSION}

The study allowed verifying that the replacement of peanut flour by Kinako flour in "paçoca-like" candies is sensorially acceptable. Partial replacement of $50 \%$ peanut flour with soy flour had better averages for all attributes evaluated, however all formulations scored averages above 4.5.

It is noteworthy that most participants rarely consume soybeans and/or soy derivatives and even so, the Kinako flour candies were appreciated by consumers. In view of this, sensory studies are needed to include this flour in different foods, in order to add the nutritional benefits present in soybean.

\section{CONTRIBUTORS}

M CAMPOS designed the study, performed the trial, collected and analyzed the data, and wrote the manuscript. C PEREIRA and A MEDEIROS worked on the data analysis and interpretation process and edited the article draft. $\mathrm{H}$ BOLINI worked on the study design process, analyzed the results, edited the draft, critically reviewed all documents and approved the final manuscript for submission.

\section{REFERENCIAS}

1. Cheng A, Raai MN, Zain NAM, Massawe F, Singh A, Wan MohtarWAAQ. In search of alternative proteins: Unlocking the potential of underutilized tropical legumes. Food Security. 2019;11:1205-15.

2. Universidade Estadual de Campinas (Brasil). Tabela Brasileira de Composição de Alimentos - TACO. NEPA, UNICAMP $4^{a}$ edição revisada e ampliada [Ebook]. Campinas: Unicamp; 2011 [cited 2017 Fev. 08]. Available from: http:// www.nepa.unicamp.br/taco/contar/taco_4_edicao_ampliada_e_revisada.pdf?arquivo=taco_4_versao_ampliada_e_ revisada.pdf 
3. Duque-Estrada P, Kyriakopoulou K, Groot W, Van der Goot AJ, Berton-Carabin CC. Oxidative stability of soy proteins: from ground soybeans to structured products. Food Chem. 2020;126499. https://doi.org/10.1016/j. foodchem.2020.126499

4. Carrão-Panizzi MC, Mandarino JMG. Kinako: um alimento funcional da soja de fácil utilização. Embrapa Soja. 2001. [cited 2017 Fev. 12]. Available from: https://ainfo.cnptia.embrapa.br/digital/bitstream/item/105492/1/ID-1797.pdf

5. Mendoza Meza DL, AhumadaBarraza C, Roa Mercado C. Efecto de lasisoflavonas de la soja enlasaludósea de adultos y niños. Salud Uninorte. 2015;31:138-52. https://doi.org/10.14482/sun.31.1.6087

6. Lima JR, Garruti DDS, Bruno LM, Araújo ÍM. Nobre ACOS, Garcia LGS. Replacement of peanut by residue from the cashew nut kernel oil extraction to produce a type paçoca candy. J Food Process Preserv. 2017;41(2):e12775. https:// doi.org/10.1111/jfpp.12775

7. Stone, H. Example food: what are its sensory properties and why is that important? 2018; npj Sci Food. 2018;2:11. https://doi.org/10.1038/s41538-018-0019-3

8. Walkeling IN, MacFie JH. Designing consumer trials balanced for first and higher orders of carry-over effect when only a subset of k samples from t may be tested. Food Qual Pref. 1995;6:299-308.

9. Stone H, Sidel J, Sensory evaluation practices. 3th ed. Redwood City: Academic Press, 2004.

10. Padhi EMT, Ramdath DD, Carson SJ, Haroke A, Blewett HJ, Wolever TMS, et al. Liking of soy flour muffins over time and the impact of a health claim on willingness to consume. Food Res Inter. 2015;77(3):491-7.

11. Dotto DMR, Colpo RR, Iop SCF, Cirolini A. Percepção dos consumidores de soja e derivados na cidade de Júlio de Castilhos (RS) - Brasil. Rev Agro Meio Amb. 2015;8(3):585-600.

12. Arruda EF, Oliveira A, Oliveira AD. Avaliação de sorvete tipo iogurte à base de soja com a adição de microrganismos probióticos. Rev Inter Episteme Transversalis. 2015;9(2).

13. Romanchik-Cerpovicz JE, Abbott AE, Dent LA. Sensory evaluation ratings and moisture contents show that soy is acceptable as a partial replacement for all-purpose wheat flour in peanut butter graham crackers. J Am Diet Assoc. 2011(12):1912-6. https://doi.org/10.1016/j.jada.2011.09.007

14. Faria WCS, Giordani MA, Arcas AS, Cavenaghi DFLC, Oliveira AP, Santos JF, et al. Novel soybean-based high protein bar rich in isoflavones improves insulin sensitivity in diabetic Wistar rats. J Food Sci Technol. 2018;55:21-32. https:// doi.org/10.1007/s13197-017-2753-y

15. Mariani M, Oliveira VR, Faccin R, Rios AO, Venkze JG. Elaboração e avaliação de biscoito sem glúten a partir farelo de arroz e farinhas de arroz e de soja. Brazilian J Food Technol. 2015;18(1):70-8. https://doi.org/10.1590/19816723.6514

16. Morais EC, Pinheiro ACM, Nunes CA, Bolini HMA. Multiple time-intensity analysis and temporal dominance of sensations of chocolate dairy dessert using prebiotic and different high-intensity sweeteners. J Sensory Studies. 2014;29:339-50. 